\title{
TEKNIK-TEKNIK DALAM SUPERVISI PENDIDIKAN
}

Diajukan untuk memenuhi tugas mata kuliah Manajemen Sekolah

Dosen Pengampu : Wahyu Bagja Sulfemi,M.Pd

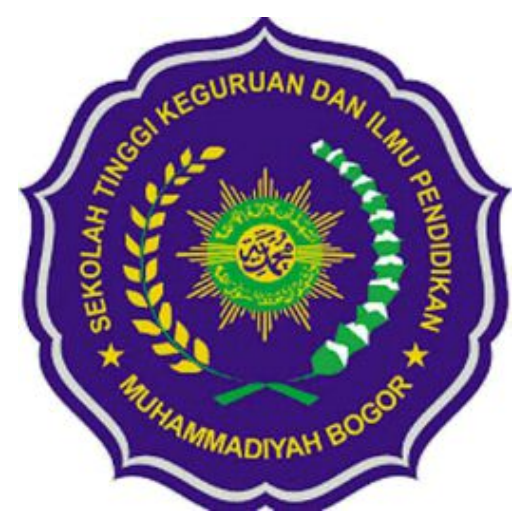

Disusun Oleh:

Maulana Sopian

0142S1A018017

PROGRAM STUDI ADMINISTRASI PENDIDIKAN

STKIP MUHAMMADIYAH BOGOR

2019 


\section{TUJUAN SUPERVISI PENDIDIKAN}

Tujuan Supervisi Pendidikan adalah perbaikan dan perkembangan proses belajar mengajar secara total. Ini berati tujuan supervisi pendidikan tidak hanya untuk memperbaiki mutu mengajar guru, tetapi juga membina pertumbuhan profesinguru termasuk di dalamnya pengadaan fasilitas yang menunjang kelancaran proses belajar mengajar, peningkatan mutu pengetahuan dan keterampilan guru, pemberian bimbingan dan pembinaan dalam hal implementasi kurikulum, pemilihan dan penggunaan metode mengajar, alat pelajaran, prosedur dan teknik evaluasi pengajaran. Jadi, sekolah yang hendak mewujudkan tujuan dalam belajar sebagaimana yang menjadi fokus pendidikan multikultural haruslah dikelola dengan kepemimpinan kepala sekolah yang kuat. Kepala sekolah tidak hanya sebagai manajer, melainkan lebih dari itu. Ia harus menjadi leader(pemimpin) (Sulfemi, $2019: 129$ ).

\section{TEKNIK-TEKNIK SUPERVISI PENDIDIKAN}

Untuk mempermudah kepala sekolah dalam pelaksanaan kegiatan supervisi diperlukan teknik-teknik supervisi. Para ahli berbeda-beda dalammerumuskan tahapan teknik-tekniksupervisi akan tetapi pada dasarnya tetap sama. Secara garis besarteknik supervisi dibedakan menjadi dua bagian,yaitu:

\section{1) Teknik perseorangan}

Yang dimaksud teknik perseorangan ialah supervisi yang dilakukan secara perseorangan, beberapa kegiatan yang dilakukan antara lain: Mengadakan kunjungan kelas (classroom visitation), Kepala sekolah datang ke kelas untuk mengobservasi bagaimana guru mengajar. Dengan kata lain, untuk melihat apa kekurangan atau kelemahan yang sekirannya perlu diperbaiki.

Mengadakan kunjungan observasi (observation visits), Guru-guru ditugaskan untuk mengamati seorang guru yang sedang mendemonstrasikan cara-cara mengajar suatu mata pelajaran tertentu. Kunjungan observasi dapat dilakukan di sekolah sendiri atau dengan mengadakan kunjungan ke sekolah lain.

Membimbing guru tentang cara-cara mempelajari pribadi siswa atau mengatasi problem yang dialami siswa.Membimbing guru dalam hal yang berhubungan dengan pelaksanaan kurikulum sekolah, antara lain: menyusun program semester, membuat program satuan pelajaran, mengorganisasi kegiatan pengelolaan kelas, melaksanakan teknik-teknik evaluasi pembelajaran, menggunakan media dan sumber dalam proses belajar mengajar, dan mengorganisasi kegiatan siswa dalam bidang ekstrakurikuler. (E \& Afriansyah, 2019)

\section{b. Macam-macam teknik supervisi individual}

Teknik supervisi individual ada lima macam yaitu:

1) kunjungan kelas, 
2) observasi kelas,

3) pertemuan individual,

4) kunjungan antarkelas, dan

5) menilai diri sendiri.

a) Kunjungan kelas

Kunjungan kelas adalah teknik pembinaan dosen atau instruktur oleh kepala Satuan Pendidikan untuk mengamati proses pembelajaran di kelas. Tujuannya adalah untuk menolong dosen atau instruktur dalam mengatasi masalah di dalam kelas. Melaksanakan kunjungan kelas

Cara melaksanakan kunjungan kelas:

1) dengan atau tanpa pemberitahuan terlebih dahulu tergantung sifat tujuan dan masalahnya,

2) atas permintaan dosen atau instruktur bersangkutan,

3) sudah memiliki instrumen atau catatan-catatan, dan

4) tujuan kunjungan harus jelas.

\section{Tahap-tahap kunjungan kelas}

Ada empat tahap kunjungan kelas.

1)Tahap persiapan. Pada tahap ini, supervisor merencanakan waktu, sasaran, dan cara mengobservasi selama kunjungan kelas.

2)Tahap pengamatan selama kunjungan. Pada tahap ini, supervisor mengamati jalannya proses pembelajaran berlangsung.

3)Tahap akhir kunjungan. Pada tahap ini, supervisor bersama dosen atau instruktur mengadakan perjanjian untuk membicarakan hasil-hasil observasi.

4)Tahap terakhir adalah tahap tindak lanjut.

\section{Kriteria kunjungan kelas}

Dengan menggunakan enam kriteria yaitu:

1)memiliki tujuan-tujuan tertentu;

2)mengungkapkan aspek-aspek yang dapat memperbaiki kemampuan dosen atau instruktur;

3)menggunakan instrumen observasi untuk mendapatkan data yang obyektif;

4)terjadi interaksi antara pembina dan yang dibina sehingga menimbulkan sikap saling pengertian

5)pelaksanaan kunjungan kelas tidak menganggu proses pembelajaran; dan 6)pelaksanaannya dikuti dengan program tindak lanjut.

b) Observasi kelas 
Observasi kelas adalah mengamati proses pembelajaran secara teliti di kelas. Tujuannya adalah untuk memperoleh data obyektif aspek-aspek situasi pembelajaran, kesulitan-kesulitan dosen atau instruktur dalam usaha memperbaiki proses pembelajaran.

Aspek-aspek yang diobservasi di dalam kelas

Secara umum, aspek-aspek yang diobservasi adalah:

1) usaha-usaha dan aktivitas dosen atau instruktur-siswa dalam proses pembelajaran,

2) cara menggunakan media pengajaran

3) variasi metode,

4) ketepatan penggunaan media dengan materi

5) ketepatan penggunaan metode dengan materi, dan

6) reaksi mental para siswa dalam proses belajar mengajar.

\section{Pelaksanaan observasi kelas}

Pelaksanaan observasi kelas ini melalui tahap:

1) persiapan,

2) pelaksanaan,

3) penutupan,

4) penilaian hasil observasi; dan

5) tindak lanjut. Supervisor: a) sudah siap dengan instrumen

observasi, b) menguasai masalah dan tujuan supervisi, dan c)

observasi tidak mengganggu proses pembelajaran.

\section{c) Pertemuan Individual}

Pertemuan individual adalah satu pertemuan, percakapan, dialog, dan tukar pikiran antara supervisor dosen atau instruktur. Tujuannya adalah:

1)memberikan kemungkinan pertumbuhan jabatan dosen atau instruktur melalui pemecahan kesulitan yang dihadapi;

2)mengembangkan hal mengajar yang lebih baik;

3)memperbaiki segala kelemahan dan kekurangan pada diri dosen atau instruktur, dan

4)menghilangkan atau menghindari segala prasangka.

\section{Jenis-jenis pertemuan individual}

Swearingen (1961) mengklasifikasi empat jenis pertemuan (percakapan) individual sebagai berikut

1) classroom-conference, yaitu percakapan individual yang dilaksanakan di dalam kelas ketika mahasiswa-mahasiswa sedang meninggalkan kelas (istirahat). 
2) office-conference, yaitu percakapan individual yang dilaksanakan di ruang kepala Satuan Pendidikan atau ruang dosen atau instruktur, di mana sudah dilengkapi dengan alat-alat bantu yang dapat digunakan untuk memberikan penjelasan pada dosen atau instruktur.

3) causal-conference, yaitu percakapan individual yang bersifat informal, yang dilaksanakan secara kebetulan bertemu dengan dosen atau instruktur

4) observational visitation, yaitu percakapan individual yang dilaksanakan setelah supervisor melakukan kunjungan kelas atau observasi kelas.

\section{Pelaksanaan pertemuan individual}

Supervisor harus berusaha mengembangkan segi-segi positif dosen atau instruktur, mendorong dosen atau instruktur mengatasi kesulitan-kesulitannya, memberikan pengarahan, dan melakukan kesepakatan terhadap hal-hal yang masih meragukan.

\section{d) Kunjungan antar kelas}

Kunjungan antar kelas adalah dosen atau instruktur yang satu berkunjung ke kelas yang lain di Satuan Pendidikan itu sendiri.

Tujuannya adalah untuk berbagi pengalaman dalam pembelajaran.

Cara-cara melaksanakan kunjungan antar kelas

Cara-cara melakukan kunjungan antar kelas:

1. harus direncanakan;

2. dosen atau instruktur yang akan dikunjungi harus diseleksi;

3. tentukan dosen atau instruktur-dosen atau instruktur yang akan mengunjungi;

4. sediakan segala fasilitas yang diperlukan;

5. supervisor hendaknya mengikuti acara ini dengan pengamatan yang cermat;

6. adakah tindak lanjut setelah kunjungan antar kelas selesai,misalnya dalam bentuk percakapan pribadi, penegasan, dan pemberian tugas-tugas tertentu;

7. segera aplikasikan ke Satuan Pendidikan atau ke kelas dosen atau instruktur bersangkutan, dengan menyesuaikan pada situasi dan kondisi yang dihadapi;

8. adakan perjanjian-perjanjian untuk mengadakan kunjungan antar kelas berikutnya.

\section{e) Menilai diri sendiri}

Menilai diri adalah penilaian diri yang dilakukan oleh diri sendiri secara objektif. Untuk maksud itu diperlukan kejujuran diri sendiri.

\section{Cara-cara menilai diri sendiri}

Cara-cara menilai diri sendiri sebagai berikut. 
1. Suatu daftar pandangan atau pendapat yang disampaikan kepada mahasiswa-mahasiswa untuk menilai pekerjaan atau suatu aktivitas. Biasanya disusun dalam bentuk pertanyaan baik secara tertutup maupun terbuka, dengan tidak perlu menyebut nama.

2. Menganalisa tes-tes terhadap unit kerja.

3. Mencatat aktivitas mahasiswa-mahasiswa dalam suatu catatan,

4. baik mereka bekerja secara individu maupun secara kelompok. (Prasojo)

\section{2) Teknik kelompok}

Teknik kelompok ialah supervisi yang dilakukan secara kelompok, beberapa kegiatan yang dapat dilakukan antara lain:

Mengadakan pertemuan atau rapat (meeting), Seorang kepala sekolah menjalankan tugasnya berdasarkan rencana yang telah disusun. Termasuk mengadakan rapat-rapat secara periodik dengan guru-guru, dalam hal ini rapat-rapat yang diadakan dalam rangka kegiatan supervisi.

- Mengadakan diskusi kelompok (group discussions), Diskusi kelompok dapat diadakan dengan membentuk kelompok-kelompok guru

bidang studi sejenis. Di dalam setiap diskusi,supervisor atau kepala sekolah memberikan pengarahan, bimbingan, nasihat-nasihat dan saran-saran yang diperlukan.

- Mengadakan penataran-penataran (inservice-training), Teknik ini dilakukan melalui penataranpenataran, misalnya penataran untuk guru bidangstudi tertentu. Mengingat bahwa penataran pada umumnya diselenggarakan oleh pusat atau wilayah,maka tugas kepala sekolah adalah mengelola dan membimbing pelaksanaan tindak lanjut (follow-up)dari hasil penataran.

Dengan demikian teknik supervisi sangat pentinguntuk dikuasai oleh kepala sekolah, tanpapenguasaan teknik dalam pelaksanaanya tidak akan berjalan baik. Dengan demikian seorang kepala sekolah tidak akan efektif kegiatan supervisinya sebelum menguasai teknik dalam bidang supervisi.Teknik supervisi akan lebih memudahkan pencapaian sasaran-sasaran dari tujuan yang telah ditetapkan, oleh sebab itu penerapan teknik dari supervisi merupakan wujud dari kemajuan sekolah untuk berkembang (Kependidikan, MUTU,KEPENDIDIKAN, \& NASIONAL, 2008). (E \& Afriansyah, 2019)

Menurut Gwynn (1961), ada tiga belas teknik supervisi kelompok yaitu:

1) kepanitiaan-kepanitiaan,

2) kerja kelompok,

3) laboratorium dan kurikulum,

4) membaca terpimpin,

5) demonstrasi pembelajaran,

6) darmawisata,

7) kuliah/studi, 
8) diskusi panel,

9) perpustakaan,

10) organisasi profesional,

11)buletin supervisi,

12) pertemuan dosen atau instruktur,

13)lokakarya atau konferensi kelompok (Prasojo)

\section{Pendekatan Supervisi}

Beberapa pendekatan supervisi yang lebih populer dikenal dengan supervisi klinis, pengembangan, dan diferensial. Masingpendekatan tersebut memiliki kekuatan dan kelemahan.

\section{a. Supervisi Klinis}

Supervisi klinis dikembangkan pertama kali berdasarkan gagasan diagnosis dan perlakuan di bidang medis oleh Morris Cogan tahun 1950 di sebuah sekolah laboratorium di Universitas Harvard. Pendekatan ini dipengaruhi oleh teori behavioristik.Kata "klinis" menunjuk pada muka antara guru dan supervisor pada pemecahan masalah reflektif, target secara langsung masing-masing kelas, dan terfokus pada guru sebagai agen perubahan.memiliki kapasitas mengembangkan kemampuan guru untuk bertanggung jawab menganalisis kinerja mereka, terbuka membantu orang lain, dan mengarahkan diri sendiri.dilakukan dalam bentuk proses tatap muka yang memungkinkan supervisor dan guru bersama membahas dan menganalisis masalah pembelajaran yang terjadi di kelas dan menemukan mengatasi masalah tersebut.

\section{b. Supervisi Pengembangan}

Supervisi pengembangan di pelopori oleh Carl D Glickman yang berbasiskan pada pengembangan seperti Erickson dan Piaget Supervisor yang menggunakan model ini memperlakukan guru sebagai individu yang berada pada berbagai tahap pertumbuhan dan pengembangan. Model ini didasarkan pada asumsi bahwa guru memiliki beragam pengalaman, kemampuan, dan tingkat pengembangan karir yang berbeda. Oleh sebab itu, supervisor menentukan kebutuhan supervisi guru berdasarkan perbedaan individual, keahlian, dan komitmen. karenanya dapat menggunakan pendekatan supervisi untuk guru yang berbedaDengan menggunakan strategi ini, Glickman et al. (2010: 192) mengemukakan bahwa Supervisorharus memilih pendekatan atas dasar kasus per kasus, menggunakan dasar pengetahuan mengelompokkan guru, observasi dan interaksi dengan guru atau kelompok terkini, dan menganalisis situasi sekarang. Dengan kata lain, supervisi pengembangan memberikan guru banyak pilihan sebagaimana keadaan guru dan mempercepat pengambilan keputusan dan menyesuaikannya setiap waktu yang diperlukan.

Menurut Clickman et al. $(2010,137)$ mengemukakan bahwa empat pendekatan pengembangan, yaitu: direktif, nondireKtif kolaboratif. 


\section{1) Gaya Control Directive}

Supervisi ini digunakan bila guru berada level pengembangan yang rendah; tidak memiliki kemauan, pengetahuan dan kecenderungan berbuat; tidak mau terlibat dalam pengambilan keputusan; supervisor lebih berkomitmen memecahkan masalah dan guru tidak; dan supervisor memiliki waktu bersama guru. Dalam gaya ini supervisor mengambil alih permasalahan guruSupervisor menetapkan tujuan dan standar yang tepat untuk dicapai guru.

\section{2) Gaya Informational Directive}

Supervisi ini digunakan bila level pengembangan guru agak rendah, tidak memiliki pengetahuan, bingung dan tidak berpengalaman, supervisor lebih peduli terhadap masalah guru, supervisor lebih dipercaya, dan waktu yang singkat. Dalam gaya ini, supervisor adalah sumber utama informasi, mengartikulasikan tujuan, dan mengarahkan tindakan.

\section{3) Gaya Behaviors Collaborative}

Supervisi ini digunakan bila level pengembangan guru yang moderat, guru dan supervisor memiliki tingkat keahlian yang sama, guru dan supervisor terlibat dalam mendapatkan keputusan, guru dan supervisor berkomitmen untuk memecahkan masalah.

\section{4) Gaya Behaviors Nondirective}

Supervisi ini digunakan bila level pengembangan guru yang tinggi, guru memiliki keahlian, guru berinisiatif memecahkan masalah, dan guru berkomitmen untuk memecahkan masalah.

\section{c. Supervisi Differensial}

Supervisi diferensial adalah salah satu pendekatan terbaru supervisi. Supervisi dipelopori oleh Allan Glatthorn. Menurut (1997: 3) bahwa supervisi diferensial merupakan pendekatan supervisi yang menyediakan pilihan jenis supervisi dan evaluasi yang sesuai dengan kebutuhan guru. Supervisi diferensialdengan mempertimbangkan perbedaan individual antara guru dan hubungan manusia antara supervisor dan guru.

\section{Pelatihan}

Pendekatan peningkatan kualitas pembelajaran yang lebih efektif dapat dilakukan melalui peningkatan kompetensi guru yang dilakukan dengan pelatihan.menurut Mahapatro $(2010 ; 285)$ pelatihan adalah kegiatan yang diselenggarakan untuk meningkatkan pengetahuan dan keterampilan orang-orang untuk tujuan tertentu. dilaksanakan melalui prosedur sistematis mentransfer pengetahuan teknis kepada karyawan sehingga dapat meningkatkan pengetahuan dan keterampilan untuk 
melakukan pekerjaan tertentu dengan matang (proficiency). Dengan kata lain, para peserta memperoleh pengetahuan teknis, keterampilan dan kemampuan pemecahan masalah dengan melakukan program pelatihan

Alasan perlunya Pelatihan

Ada banyak alasan bagi supervisor untuk melakukan pelatihan guru menurut (2004; 126), meliputi:

- peningkatan kepuasan kerja dan semangat

- peningkatan motivasi guru,

- peningkatan efisiensi dalam prosesyang maksimal,

- peningkatan kapasitas untuk mengadopsi teknologi dan metode baru,

- peningkatan inovasi dalam strategi dan

- meningkatkan citra lembaga. (sabandI, 2013)

\section{Kesimpulan}

Teknik-teknik supervisi secara garis besar di bedakan menjadi 2 yakni teknik perorangan dan teknik kelompok. Teknik perseorangan Yang dimaksud teknik perseorangan ialah supervisi yang dilakukan secara perseorangan, beberapa kegiatan yang dilakukan antara lain: Mengadakan kunjungan kelas (classroom visitation), Kepala sekolah datang ke kelas untuk mengobservasi bagaimana guru mengajar. Dengan kata lain, untuk melihat apa kekurangan atau kelemahan yang sekirannya perlu diperbaiki.Teknik supervisi individual ada lima macam yaitu:
1) kunjungan kelas,
2) observasi kelas,
3) pertemuan individual,
4) kunjungan antarkelas, dan
5) menilai diri sendiri.

Teknik kelompok Teknik kelompok ialah supervisi yang dilakukan secara kelompok, beberapa kegiatan yang dapat dilakukan antara lain:

Mengadakan pertemuan atau rapat (meeting), Seorang kepala sekolah menjalankan tugasnya berdasarkan rencana yang telah disusun. Termasuk mengadakan rapat-rapat secara periodik dengan guru-guru, dalam hal ini rapat-rapat yang diadakan dalam rangka kegiatan supervisi.

Menurut Gwynn (1961), ada tiga belas teknik supervisi kelompok yaitu:

1) kepanitiaan-kepanitiaan,

2) kerja kelompok,

3) laboratorium dan kurikulum,

4) membaca terpimpin,

5) demonstrasi pembelajaran,

6) darmawisata, 
7) kuliah/studi,

8) diskusi panel,

9) perpustakaan,

10) organisasi profesional,

11)buletin supervisi,

12) pertemuan dosen atau instruktur,

13)lokakarya atau konferensi kelompok (Prasojo) 


\section{$\underline{\text { Soal }}$}

1. Di dalam supervisi terdapat pendekatan-pendekatan supervisi, di bawah ini mana yang merupakan pendekatan supervisi..
A. Pendekatan moral
B.pendekatan supervisi klinis *
C. Pendekatan supervisi klinik
D.Pendekatan supervisi perkembangan
E. Pendekatan Difrensi

2.Supervisor harus memilih pendekatan atas dasar kasus per kasus, menggunakan dasar pengetahuan mengelompokkan guru, observasi dan interaksi dengan guru atau kelompok terkini, dan menganalisis situasi sekarang. Kutipan diatas merupakan ungkapan dari...
A. Moris cogan
B.Gwyn
C.Morris Cogan
D.Glickman et al *
E. Tidak ada jawaban yang tepat.

3.Berikut ini yang bukan merupakan macam-macam teknik supervisi perorangan adalah..
A.Kunjungan kelas
B.observasi kelas
C.Kunjungan antar kelas
D.menilai orang lain *
E.pertemuan individual

4.menurut Swearingen ada berapa jenis pertemuan individual..
A. Satu
B.Dua
C.Tiga
D.Empat *
E.Lima 
5.percakapan individual yang dilaksanakan setelah supervisor melakukan kunjungan kelas atau observasi kelas merupakan pengertian dari...
A. observational visitation *
B.causal-conference
C.office-conference
D.classroom-conference
E.room-conference

6. Dalam macam-macam supervisi individual terdapat kunjungan antar kelas, dibawah mana yang merupakan tunjuan dari kunjungan antar kelas..
A.untuk membangun kekompakan
B. Untuk berbagi pengalaman dalam pembelajaran *
C.untuk berbagi ide
D. Untuk menambah relasi
E. Semua jawaban salah.

7. Apa yang di maksud classroom conference..

A.percakapan individual yang dilaksanakan di dalam kelas ketika mahasiswa-mahasiswa sedang meninggalkan kelas (istirahat).

B.percakapan individual yang dilaksanakan.

C.percakapan individual yang dilaksanakan di ruang kepala Satuan Pendidikan atau ruang dosen atau instruktur, di mana sudah dilengkapi dengan alat-alat bantu yang dapat digunakan untuk memberikan penjelasan pada dosen atau instruktur.

D.percakapan individual yang bersifat informal, yang dilaksanakan secara kebetulan bertemu dengan dosen atau instruktur

E. percakapan individual yang dilaksanakan setelah supervisor melakukan kunjungan kelas atau observasi kelas.

8. Dibawah ini mana yang bukan merupakan tahap-tahap kunjungan kelas..
A. Tahap persiapan
B. Tahap pengamatan
C. Tahap akhir kunjungan
D. Tahap penentuan *
E. Tahap tindak lanjut

9. Ada berapa teknik-teknik supervisi... 

A. Dua *
B. Tiga
C. Empat
D. Lima
E. Satu

10. Siapakah yang mengemukakan bahwa terdapat 13 teknik supervisi kelompok.
A. Moris cogan
B.Gwynn *
C.Morris Cogan
D.Glickman et al
E. Tidak ada jawaban yang tepat.

\section{ESSAI}

1. Coba sebutkan macam-macam teknik supervisi individu? jawaban.

1) kunjungan kelas,

2) observasi kelas,

3) pertemuan individual,

4) kunjungan antarkelas, dan

5) menilai diri sendiri.

2. Hal apa yang di perlukan untuk melakukan penilaian diri sendiri? Jawaban.

Kejujuran diri.

3.coba kemungkakan 2 jenis pertemuan individual menurut Swearingen ? Jawaban

a.classroom-conference, yaitu percakapan individual yang dilaksanakan di dalam kelas ketika mahasiswa-mahasiswa sedang meninggalkan kelas (istirahat).

b.office-conference, yaitu percakapan individual yang dilaksanakan di ruang kepala Satuan Pendidikan atau ruang dosen atau instruktur, di mana sudah dilengkapi dengan alat-alat bantu yang dapat digunakan untuk memberikan penjelasan pada dosen atau instruktur. 
4.Supervisor harus memilih pendekatan atas dasar kasus per kasus, menggunakan dasar pengetahuan mengelompokkan guru, observasi dan interaksi dengan guru atau kelompok terkini, dan menganalisis situasi sekarang. Kutipan diatas merupakan ungkapan dari...

Jawaban.

Glickman et al

5.apa itu Observasi kelas ?

Jawaban.

Observasi kelas adalah mengamati proses pembelajaran secara teliti di kelas. Tujuannya adalah untuk memperoleh data obyektif aspek-aspek situasi pembelajaran, kesulitan-kesulitan dosen atau instruktur dalam usaha memperbaiki proses pembelajaran. 


\section{Daftar Pustaka}

E, R. M., \& Afriansyah, H. (2019). Administrasi Dan Supervisi Pendidikan. pp. 2-4.

Prasojo, S. L. (n.d.). Supervisi Pendidikan.

sabandI, A. (2013). Supervisi Pendidikan Untuk Pengembangan Profesionalitas Guru Berkelanjutan.

Jurnalllmiah Ilmu Pendidikan, 3-7.

Sulfemi, Wahyu Bagja.(2019).Manajemen Sekolah.

Sulfemi, Wahyu Bagja. (2018). Modul Manajemen Pendidikan Non Formal. Bogor:

STKIP Muhammadiyah Bogor. 